\title{
THEORETICAL AND CONCEPTUAL ISSUES OF THE DECENTRALIZATION OF REGIONAL DEVELOPMENT POLICY
}

\author{
Borislav Borisov ${ }^{1}$, Evelina Parashkevova ${ }^{2 \star}$, Yuliyan Gospodinov ${ }^{3}$, Mariela \\ Stoyanova ${ }^{4}$ \\ ${ }^{1}$ Prof. DSc, D. A. Tsenov Academy of Economics - Svishtov, BULGARIA, \\ b.borissov@uni-svishtov.bg \\ ${ }^{2}$ Assoc. Prof. PhD, D. A. Tsenov Academy of Economics - Svishtov, BULGARIA, \\ e.parashkevova@uni-svishtov.bg \\ ${ }^{3}$ Head Assist. Prof., PhD, D. A. Tsenov Academy of Economics - Svishtov, BULGARIA, \\ y.gospodinov@uni-svishtov.bg \\ ${ }^{4}$ Assist. Prof. PhD, D. A. Tsenov Academy of Economics - Svishtov, BULGARIA, \\ m.stoyanova@uni-svishtov.bg \\ ${ }^{*}$ Corresponding author
}

\begin{abstract}
Integrated territorial investments are a fundamentally new approach to the implementation of regional policy. The approach requires decentralization of the decision-making process and active participation of citizens in this process. The bottom-up approach involves identifying the needs of the community and looking for alternatives to meet those needs. The choice of the best alternative, ie. the choice of a specific measure or project implies the application of adequate working mechanisms to ensure the involvement of the general public. There are various theories about how to encourage and motivate citizens to participate in public decisions that have a direct impact on them and their way of life. Different strategies and approaches are applied, their effectiveness is different, and it is difficult to find a universal solution.

The aim of this article is to bring out the main theoretical and conceptual issues related to the role, importance, tools for civic participation in public policy-making processes in general and in relation to regional policy in particular. On this basis, an iterative model for applying the bottom-up approach to inclusion in integrated planning will be proposed.

Content analysis of documents and empirical research will outline the main steps that would be useful in the process of decentralization and promoting participation. Based on the deduction and induction, the main barriers and limiting factors will be identified, which so far hinder the more active participation of civil society, business and other organizations in the process of making decisions for regional development. The aim is to outline the main groups of constraints and to suggest possible reactions to them. The framework for decentralization of the process of regional development and stakeholder involvement will be outlined, as well as good practices, existing hypotheses about the commitment of public institutions to ensure inclusion, opportunities to build an environment that ensures a high degree of integration of public policies.
\end{abstract}

Keywords: decentralization, integrated territorial investments, regional policy

\section{INTRODUCTION}

Civic participation in the processes of formulating, implementing and monitoring public policies is part of the democratic processes in a society. Ensuring the effectiveness and efficiency of inclusion is a challenge that 
is related to the attitudes of managers and those governed, as well as to the existing regulatory and strategic framework defining this inclusion.

At European level, the effort is not only to bring politics closer to the people, but also for them to participate directly in its various forms and manifestations. The Charter of Fundamental Rights of the European Union (2012 / C 326/02) (Charter of Fundamental Rights of the EU, 2016) is also integrated into the Treaty on European Union (Consolidated Version of the Treaty on EU, 2012), thus becoming the norm defining Member States' commitments on citizenship.

The direct expression of opinion and involvement in public processes and decisions concerning the future is based on active civic participation. It contradicts the applied bureaucratic management practices, which stand out with a technocratic approach and limited consideration of group interests. Democratic principles of governance presuppose that there must be such levers - legislative and methodological, that enable anyone interested or influenced by a decision to participate in its development. However, this is practically impossible and for this reason various formal and informal structures of civil society are created, which are an expression of interest groups, most often in different sectorial areas of public life - culture, sports, social activities, education, health, ecology, regional development, etc., etc.

The participation of the citizens in the implementation of the integrated territorial investments in the process of regional development turns out to be extremely important. Achieving sustainable development is possible through the involvement of the public, which will be directly influenced by the implementation of a policy. This is a basic principle and requirement in the European regional policy for the programming period 2021-2027.

In practice, civic participation is an extremely complex task. Despite the preconditions created for broad consultation through the regulation of this process in normative acts and standards (Council of Ministers of the Republic of Bulgaria, 2010), civic participation is still weak. Although the principles of the Council of Europe's Code of Good Practice for Civic Participation (INGO Conference, 2009) are enshrined in a number of documents at national, regional and local level in Bulgaria, their implementation in practice requires targeted interventions, as participation is still limited at this stage. The search for the main barriers and constraints that currently hinder the more active participation of civil society, business and other organizations in the decision-making process for regional development is a challenge. It can, with the help of adequate tools, answers questions related to with the approaches and methods to ensure real decentralization of regional development policy through pluralism and democratic inclusion. Based on the existing concepts of civic participation and the widely proclaimed bottom-up approach, solutions are sought to ensure effective and real participation in regional development decision-making.

\section{LITERATURE REVIEW REGARDING THE DECENTRALIZATION OF REGIONAL DEVELOPMENT POLICY}

Decentralization, according to a number of authors, implies the broad involvement of stakeholders in the decision-making process, which is extremely important and very difficult (Litvack \& Seddon, 1999) (Levinson, 2010) (Rebell, 2018) (Mihaylov, 2012). Several theories and models have been found in the scientific literature examining the relationship between power and society. Arnstein presented one of the first concepts of the role of civic participation. It distinguishes three main forms: non-participation, tokenism and citizen power in the so-called Ladder of Citizens 'Participation model (Arnstein, 1969). Critics of this theory, such as Burns, however, point out that it is suitable for specific government programs, making the model unsuitable for studying citizens (Burns,, Hambleto, \& Hoggett, 1994). According to other authors, real decentralization implies not only the involvement of citizens in policy-making, the process of democratization implies the transformation of power into a shared function, ie. involvement in the process of implementation, monitoring and evaluation of public policies. Researchers such as Agrawa and Ribot (Agrawal \& Ribot, 1999) see this process as part of a targeted state strategy to enable decision-making and the exercise of power in that part of society that will be directly affected by these decisions. Largely, Therkildsen, who considers the involvement of the local community in the control of resources, their organization and the implementation of structural regional changes to increase regional competitiveness, presents a similar view of the role of civic participation (Therkildsen, 1988) (Ambrose , 2013). This concept has been criticized for its inapplicability or partial applicability only at the decision-making stage (Rowe \& Frewer, 2005). Authors such as Cheema and Rondinelli (Cheema \& Rondinelli, 2007) divert attention. They believe that civic participation is largely influenced by a complex combination of external factors - political, social, economic and historical. For this reason, tracking the impact on the process and quality of local service delivery is a difficult task, especially given the fact that these factors vary in intensity and content from country to country. In this way, they reject the possibility of defining universally applicable models. 
In Bulgaria, decentralization-based decentralization is gaining popularity in the pre-accession period 20002006. The next two programming periods 2007-2013 and 2014-2020 are looking for different tools to involve stakeholders in regional policy-making processes.development. The legal framework in the country regarding the introduction of a bottom-up approach undergoes a number of changes and each subsequent update or adoption of a new strategic document aims to clarify key aspects, principles, guidelines and regulate more effective implementation of the overall decentralization toolkit (Law on local self-government and local administration, 2021) (Law on the Administrative and Territorial Organization of the Republic of Bulgaria, 2021) (European Charter of Local Self - Government, 2017) (European strategy for innovation and good governance at local level, 2007). Despite the efforts to achieve the most effective reduction of imbalances between the territories and the application of the principles of deconcentration of governance, with emphasis on more effective involvement of citizens and their empowerment, there are still weaknesses and problems in the regional system of Bulgaria.

In the programming period 2021-2027, the country pursues a regional policy based on the approach of integrated territorial investment, and it is expected that it will overcome the deepening territorial disparities in the economic and social dimension. More power is delegated to regional and local authorities to decide on projects to be funded. The guidelines are for this to be a process in which civil society is actually involved. The arguments for applying this new approach stem from the concept that it is at the local level that the needs of the specific territory can be most accurately determined and its endogenous potential can be used in the most optimal way. This requires the implementation of effective mechanisms to ensure broad participation in regional policy processes. However, the expertise for institutional involvement and real decentralization of regional development policy is questionable. The lack of a functional and institutional system and mechanisms for conducting a decentralized regional development policy inevitably poses a risk to the results. This and the lack of civic education and attitude to participate in the processes of formulating public policies, there are serious structural problems with regard to regional development at various levels.

\section{MODERN FORMS OF CIVIC PARTICIPATION IN PUBLIC PROCESSES}

Civic participation can be defined as all the political and social practices that citizens use to influence any dimension of public affairs (Guide for evaluating participatory processes. Short Guides for citizen participation 3, 2013). Citizens can participate in social processes individually or in groups, uniting in different organizations, depending on the nature of the problem that affects them. Most often, this takes the form of non-governmental organizations (NGO), which are voluntary self-governing bodies or organizations created to pursue essentially non-profit goals of their founders or members (Recommendation $\mathrm{CM} / \operatorname{Rec}(2007) 14$ of the Committee of Ministers to member states on the legal status of non-governmental organisations in Europe, 2007). Forms of civic participation can be reduced to four: information, consultation, dialogue and partnership.

- Information - It is applied at all stages of the process and does not require interaction and involvement. This is a one-way action from the government to the citizens, which involves them in the decisions.

- Consultation - In this form of initiative, the authorities seek the opinion of civil society organizations on specific topics or policy changes. The consultation includes information on planned policy changes and an invitation to comment, comment and feedback. The initiative and the topics come from the authorities. Consultation is appropriate at all stages of the process and especially at the stages of policy development, implementation monitoring and regulatory changes.

- Dialogue - The dialogue initiative can be on both sides, and the dialogue itself takes two forms: broad or cooperation-oriented. Broad dialogue is a two-way communication, the result of mutual interest and potential shared goals to ensure a regular exchange of views. Forms range from open public hearings to specialized meetings between NGOs and authorities. The discussion is wide-ranging and not necessarily related to an ongoing policy development process. The cooperation-oriented dialogue is based on mutual interest in developing a specific policy. It usually leads to joint recommendations, strategy or legislation. Meetings are frequent or regular and lead to agreed results. Dialogue is very valuable at all stages of the process, but it is key to setting the agenda, developing and reformulating decisions.

- Partnership - The partnership implies shared responsibilities at each stage of the agenda from the setting of the agenda through the development, decision-making and implementation of the policy. This is the highest form of participation. There is close cooperation at this level, while preserving the independence of civil society organizations. They have the right to campaign and act independently of their partnership. Possible activities in partnership are the delegation of specific tasks to civil society organizations, forums and the establishment of joint decision-making bodies, including the allocation of resources. Partnerships can be 
formed at any stage of the process and are particularly suitable for setting the agenda or implementing policies.

Some instruments or mechanisms such as e-participation, participation capacity building, structures for cooperation between NGOs and public authorities, framework documents for cooperation between NGOs and public authorities could have a strong positive effect on civic participation (Code of good practice for civic participation in the decision-making process, 2009). In this regard, public councils, advisory councils are formed, mixed working groups are created with the participation of representatives of the administration and citizens, external receptions are organized, opportunities are provided for citizens to participate in committee meetings and municipal council sessions. The Internet is maintained sites of the administrations, where important information for the public is published in a timely manner, with the possibility to send opinions, suggestions, comments and feedback.

Citizen participation can be cooperative or confrontational. Cooperatives occur when ordinary citizens (or their representatives) are involved in the work of various advisory bodies to state institutions. Confrontational participation occurs when groups of citizens who are oppressed, rejected or marginalized begin to insist on their involvement in the decision-making process (Daynov, 2021).

It should be borne in mind that although civic participation is generally accepted and included as an important condition in many regulations, strategic documents and methodological developments, it does not always manifest itself, and there is no guarantee that it will be useful. Here we should take into account not only the openness of the government to the opinion of citizens, but also the capacity of civil society representatives themselves. In this regard, whether and how well they know the issues under discussion, whether they can present and defend their views to the public, whether they risked conflict with those in power, had leadership and public speaking skills to engage others, and generated support for various causes and many others.

With regard to regional development policy, civic participation is regulated in the Regional Development Act and the Regulations for the Implementation of the Regional Development Act. The latter stipulates that state bodies and local self-government bodies inform the public in a timely and appropriate manner about the nature and nature of documents and actions related to the development, approval, adoption, updating, implementation, monitoring and evaluation of strategic planning documents spatial development, the need, the potential benefits and their consequences, as well as the results achieved. The norm contains prescriptions for obligatory public consultations, prior to the adoption of the National Concept for Regional and Spatial Development, the integrated territorial strategies for development of the regions for level 2 planning and the plans for integrated development of the municipalities. Specific forms of inclusion are described in various methodological developments, but the lack of experience and expertise makes their implementation difficult.

Active civic participation in social processes is a measure of the quality of democracy (Mechanisms and proposals for improving the environment for civic participation in the field of healthcare, 2019).

At the same time, it must be seen in a broad sense. In order to be effective, citizen participation should not be limited to informing or participating in the discussion of various issues of public interest and policymaking, but also to it also occurs in the implementation and enforcement of policies, in their monitoring and control, as well as in the preparation of their interim and ex-post evaluations. This would ensure transparency and respect for the principles of good governance.

The participation of citizens and NGOs in the policy-making and decision-making process is a condition for open, responsible and effective governance. The creation, adoption and implementation of management decisions after and in the context of consultation and cooperation with the civil sector is a prerequisite for making better decisions in the public interest. Although the forms of citizen participation can be varied, their functioning at different levels of the political system is a condition for its democracy and legitimacy (Analyzes and models for improving citizen participation in the processes of formulation, implementation and monitoring of regional policy, 2019).

\section{ASSESSMENT OF THE ENVIRONMENT FOR CIVIC PARTICIPATION IN DECENTRALIZATION OF REGIONAL DEVELOPMENT POLICY}

There are different methodologies for analysis and evaluation of the environment for civic participation in regional development. This is also the case with the Bulgarian Center for Non-Profit Law from 2015, applied to calculate the Civil Participation Index. The index is an integral indicator formed by the assessments of three areas of civic participation - environment, practices and impact. The analysis shows an increase in the 
Index, respectively from 3.29 in 2015 to 3.32 in 2017 (Hristova \& Andreeva, 2018). The next assessment of the Index is currently being made and will determine its levels for 2021. The area "Environment for Civic Participation" examines the state of two indicators: 1. Legislation and 2. Institutional environment

Here will be presented the author's methodology, which was tested in the assessment of the environment for civic participation in the formation of local policies for regional development in an average Bulgarian municipality - Lovech. Without claiming to be representative, the situation presented largely reflects the overall picture in most Bulgarian municipalities.

For the purposes of the evaluation, a specially developed questionnaire was used, which was distributed to the employees of the municipal administration and civil society organizations. The questionnaire includes 34 questions in three main areas - citizens' trust in local government (6 questions), the professionalism of local government in shaping public policies (6 questions) and the attitude of local government to the nongovernmental sector and the target groups for which it works (22 question).

The answers to the questions were evaluated on a three-point scale - the answers "No" received a score of 2 , which is a bad condition of the parameter, the answers "Partly" received a score of 3 , corresponding to an average condition, the answers "Yes" means that the parameter received a score of 4 ., which is identified with good condition. In order to avoid accidental and uncertain answers, respondents were given the opportunity to say, "I can't answer". These responses were not taken into account when calculating the average scores of the individual responses and the average score for the whole population.

To the first question: whether the public policies of the local government are determined taking into account the role of the municipal administration and the municipal council in protecting the public interest, the representatives of the administration answered categorically with "Yes", ie. This statement is fully confirmed, which means that local authorities defend the interests of citizens, while NGO representatives responded with "Partially", which may mean that there are areas for which this statement is true, but also those for which there is the presumption that it is not. The opinion of the respondents - employees of the administration and representatives of the non-governmental sector, on the question of whether the local public interests guide the distribution of the municipal budget is more definite. The average score of their answers is 3.75, and of NGOs - 4.00 .

The differences between the answers of the two groups of respondents to the third question - can they confirm that the municipal administration and the municipal council encourage citizens, NGOs, local media and other groups to actively participate in discussing strategies, plans and programs they develop and adopt, are minimal. The answers of the employees are estimated at 3.63 and those of the NGOs at 3.5. Obviously, measures should be taken in this area to improve the work of the administration in encouraging citizens to participate more actively in the discussion of the main strategic and program documents regulating local policies.

On the fourth question - whether the municipal strategies, plans and programs have clear indicators of results that allow monitoring and evaluation of their implementation, employees give a lower score than citizens - 3.87, compared to 4.00 for NGO representatives. This can be explained by the fact that citizens are not professionally trained enough to assess the quality of planning documents, and employees are selfcritical, knowing that there is still much to be desired.

Whether the opinion of the citizens is sought from the very beginning of the process of making important strategic decisions, as their representatives are involved in the development of strategies, plans and programs, is the fifth question. Employees mostly answered "Yes", with a score of 3.75 , but citizens disagreed and received a score of 3.5, which was between good and medium. Assessments are lower on the question of whether public consultations with citizens, individual stakeholders and associations are held periodically, and not only in the event of a problem or the forthcoming adoption of a new strategy, plan or program. The average score of the employees is 3.43 , and of the NGOs - 3.5.

The next two questions - whether the municipal administration provides free access to all stakeholders to public procurement documents and decisions in connection with the award of the contract and whether public consultation with citizens, individual stakeholders and civic associations is regulated by special regulations and regulations, receive maximum marks from both groups of respondents.

On the ninth question - whether the public authority has identified the key stakeholders (which includes NGOs, business, local media and other interest groups) and whether this list is subject to constant review and updating, municipal officials have massively stated "I cannot answers ", which rather means that they have no information about the existence of such a practice. This is confirmed by the responses of NGOs, 
which are estimated at 2.5. It is clear that improvements can be sought here. The tenth question is "Can you confirm that techniques for the consultation process have been introduced in the municipal administration and the municipal council (advisory hearing, civil jury, participation in the budget process, etc.?"). The answers are 4 for the employees and 3.5 for the NGOs, respectively. It is obvious that there are some mechanisms in place to consult with citizens, but they believe that there are untapped opportunities.

Assessments are relatively low as to whether, if changes in policy and service delivery are needed, they are the result of surveys, reports, consultations, complaints and other methods of surveying citizens. The answers of the employees are estimated at 3.29, and those of the NGOs at 2.5. The assessments received from the answers regarding whether the Municipal Council has adopted an ordinance (procedure, methodology) for strategic and operational assessment of public policies are even lower. Employees give a score of 2 and NGOs a score of 2.5. It is logical in this situation and the answers given to the question whether the municipal administration takes into account the results of its evaluation, in the implementation of its public policies, to be low -3.86 for employees and 3.00 for NGOs.

With average scores of 3.00 from both groups, the practice of local government to periodically analyze its main functions and public services provided is assessed in order to assess their implementation and impact, and the results of the analyzes are made available to the public in an appropriate manner.

The following are three components that were rated by both groups with 4.00 . These are first the municipal administration and the municipal council take and implement decisions in a way that is open, transparent, accountable and timely, in accordance with rules and regulations, and that complies with international standards of good practice. Second there is a procedure for appealing the orders of the mayor and the decisions of the municipal council by the citizens and the civil associations, which is widely accessible and understandable Third the meetings of the municipal council are open to the public and the media, and the agenda and documents are publicly available.

The representatives of the municipal administration did not answer the question whether the municipal administration has developed an operational and strategic plan for work with specified strategic and operational goals (outside the municipal development plan or PIRO) which aims to improve work with civic associations, improve municipal services and encouraging civic participation in decision-making. Rather, it should mean that there is no such plan. NGO representatives gave an average score of 3.00 on this issue. The openness of the local government to the media is the next issue, as the employees think that their practice in this regard is good (4.00), while the representatives of NGOs rate it at 3.5.

The following questions from the questionnaire, from № 20 to № 25 address areas that were rated with a maximum score of 4.00 by both groups of respondents. They concern the practices of introducing ethical standards, the control over the decisions of the administration, the public procurements, the selection of the employees, their training and the evaluation of the implementation. These issues relate to the level of trust of citizens in local government and the assessment of its professionalism. Obviously, they are highly valued.

Whether the municipal administration is taking action to identify and implement good practices and new decisions in connection with ensuring civic participation in making important strategic decisions for the development of the municipality is the next question, which employees give a score of 3.37 , and NGOs quite close to 3.35. Officials believe that the budgeting process involves active rather than formal consultation with all stakeholders and gives a score of 4.00 , but citizens disagree and stick to the average of 3.00. It is also believed that the municipal administration participates in various projects and / or forms of inter-municipal cooperation in order to improve its activities and services for citizens. The average of the employees' assessments is 3.62, while NGOs give 4.00 .

For the next three questions, the employees gave 4.00 and the representatives of the civil sector - 3.50. First the municipal administration and the municipal council guarantee the social inclusion of all social groups and take anti-discrimination measures in all areas of its policy. Second the municipal administration and the municipal council actively promote diversity and cohesion in the interest of all citizens by providing resources, supporting and financially supporting the activities of non-governmental organizations, promoting dialogue and partnerships between different major social partners. Third the municipal administration and the municipal council set clear goals for improving social cohesion and maximizing the potential of cultural diversity by promoting greater intercultural communication and interaction. Municipal officials have chosen not to answer the question of whether the municipal administration and the municipal council have developed and adopted separate plans for specific disadvantaged groups (ie the Equal Access Program, the Children's and Youth Rights Program, social programs, etc.). On the other hand, the answers of the social partners is 3.50 , ie. they believe that such programs exist, but not in all areas, or that their scope is 
insufficient. To the question whether the Municipal Council and the municipal employees, together with all strategic partners, guarantee the equality goals to be included and developed in the strategies, plans for development and provision of public services, the answers of the employees give an average score of 3.00 and those of NGO - 3.5. Interestingly, the assessments of the administration are quite self-critical, while the society evaluates their efforts to ensure equality of citizens, higher, although not with the maximum assessment. To the last question - whether access to information for citizens is provided to reports, procedures, projects and other documents / without classified information / concerning the activities of the municipal administration and the municipal council, both groups of respondents answered "Yes", which forms an average score. 4.00 .

The average assessment of the environment for civic participation in the activities of local government in the municipality of Lovech, given by employees of the municipal administration is 3.76, and that of representatives of non-governmental organizations - 3.57. As you can see, the differences are not big. It is more important to highlight those areas where the attitude of local authorities towards civic associations is considered not good enough, where trust between them is lost or the professionalism of employees is not at a high enough level. The problem areas where improvements can be sought at the local level are:

- Insufficient incentives for citizens to participate in discussions of strategies, plans and programs. If they are invited to such discussions, it becomes "post factum" and not at the stage of their development;

- Although consultations with citizens are held, this is not periodic, but in case of problems or a legal requirement to hold a public hearing;

- The municipal administration and the municipal council have not identified key stakeholders to address on specific issues that concern them;

- Changes in public policies are most often made at the discretion of local authorities and not because of surveys, reports, consultations, complaints and other methods of polling citizens;

- No ordinance, procedure or methodology for strategic and operational evaluation of public policies has been adopted. This is the reason why the local government does not take into account the results of its evaluation in the implementation of its public policies. It does not periodically analyze its main functions and the public services provided in order to assess their implementation and impact;

- Setting goals of the municipal administration is identified with the strategic and operational goals set in the municipal development plan, but do not have them, specifically for the work of the administration, according to the requirements of the Law on Administration;

- The activity of the citizens in the discussion of the municipal budget is low. The reason for this may lie in the inappropriate and incomprehensible way of presenting it to the population;

- Equality of all categories of the population, incl. of people with disabilities and marginalized groups should be a key principle in developing strategies, plans and programs.

The presented methodology is an innovative tool for mapping the existing framework in practical terms on the integration of citizen participation in the processes of strategic planning of regional development at the local level.

\section{CHALLENGES AND BARRIERS TO CIVIL PARTICIPATION IN THE DECENTRALIZED DEPARTMENT OF REGIONAL DEVELOPMENT IN BULGARIA}

The Code of Good Practice for Civic Participation in Decision-Making, adopted in 2009 by the Committee of Ministers of the Council of Europe, addresses several fundamental principles in support of decentralization through inclusion (INGO Conference, 2009): participation, trust, accountability and transparency, independence. These principles are reflected in the relationship of the individual with society in the four dimensions that form modern society: political; socially; culturally; economically.

The scientific literature identifies five goals that are realized through decentralization of the process of regional development, namely (Kraft \& Furlong, 2020): integration of public values in decisions, which is the foundation of democracy; improving the quality of management decisions by enriching the points of view and discovering new facts, circumstances, dependencies; managing conflicts between stakeholders and finding compromises regarding their interests; building trust in the institutions and a higher degree of efficiency of the administration and its interaction with the public; informing and educating the public about the work of the administration, its commitments, powers and scope of action and creating preconditions for building capacity for interaction. 
The emphasis is on participatory participation and participation, which allows for a real impact on the results of ongoing social processes. The thesis is that "participation without redistribution of power is an empty and frustrating process for the powerless." This allows those in power to claim that all points of view have been taken into account, but only some of these countries benefit." (Kraft \& Furlong, 2020). These statements are also confirmed by the research of White, (White, 1996) who classifies participation (see Table 1).

Table 1. Classification of participation according to White

\begin{tabular}{|c|c|c|c|}
\hline $\begin{array}{c}\text { Form of } \\
\text { participation }\end{array}$ & $\begin{array}{c}\text { What does "participation" } \\
\text { mean for public } \\
\text { authorities? }\end{array}$ & $\begin{array}{l}\text { What does "participation" } \\
\text { mean for the } \\
\text { participants? }\end{array}$ & $\begin{array}{l}\text { Why there is } \\
\text { "participation"? }\end{array}$ \\
\hline Nominally & $\begin{array}{l}\text { Legitimation - to show that } \\
\text { they are doing something }\end{array}$ & $\begin{array}{l}\text { Inclusion - to maintain } \\
\text { some access to potential } \\
\text { benefits }\end{array}$ & Showiness \\
\hline Instrumental & $\begin{array}{l}\text { Efficiency - to limit the } \\
\text { contribution of funders, to use } \\
\text { the contribution of the } \\
\text { community and to make } \\
\text { projects more profitable }\end{array}$ & $\begin{array}{l}\text { Costs - time spent on } \\
\text { project-related work and } \\
\text { other activities }\end{array}$ & $\begin{array}{l}\text { As a means of } \\
\text { achieving efficiency } \\
\text { and local initiatives }\end{array}$ \\
\hline Representative & $\begin{array}{l}\text { Sustainability - to avoid } \\
\text { dependence }\end{array}$ & $\begin{array}{l}\text { Leverage - to influence the } \\
\text { form that the project takes } \\
\text { and its management }\end{array}$ & $\begin{array}{l}\text { To give people a voice } \\
\text { in determining } \\
\text { development }\end{array}$ \\
\hline Transforming & $\begin{array}{l}\text { Empowerment - to enable } \\
\text { people to make their own } \\
\text { decisions, to understand what } \\
\text { to do and to take action }\end{array}$ & $\begin{array}{l}\text { Empowerment - to be able } \\
\text { to decide and act on their } \\
\text { own }\end{array}$ & $\begin{array}{l}\text { Both as a means and } \\
\text { as an end, a continuing } \\
\text { dynamic }\end{array}$ \\
\hline
\end{tabular}

In practice, various social, political, cultural and economic factors distance citizens from participating in socio-political life. This is the reason why a number of authors point out the need for reform in terms of civic participation processes and expected contributions to public policies in the field of regional development. This reform needs to be accompanied by capacity building and knowledge. In this regard, Collins and Aisen (Collins \& Ison, 2009) focus on learning - learning in larger groups and entire societies. They present as basic prerequisites for the involvement of citizens in government, ie. in decentralization through empowerment, publicity, civic education, synergies and partnerships.

At European level, guided by scientific advances, there is a need to ensure participation by "creating a favorable environment, namely the rule of law, support for fundamental democratic principles, political will, favorable legislation, clear and precise procedures, long-term support and resources for a sustainable civil society, as well as shared spaces for dialogue and cooperation. These conditions allow for constructive cooperation between NGOs and public authorities, built on mutual trust and understanding of participatory democracy. (INGO Conference, 2009)"

The International Organization of Non-Governmental Organizations of the Council of Europe also highlights the need to outline the stages of management decision-making and the various opportunities for interaction between public authorities and the civil sector. The implementation of these stages is based on generally accepted horizontal instruments for civic participation. They are related to providing opportunities for electronic participation, capacity building, creation of permanent and ad hoc structures for cooperation between NGOs and public institutions, Framework documents for cooperation between NGOs and public authorities.

Public policies are a reflection of the relationship between government and citizens. Theoretically (Najam, 2000), there are 4 possible positions regarding the goals of these two groups. 


\section{OBJECTIVES OF Public Sector and NGOs}

\begin{tabular}{|c|c|c|}
\hline Approaches / tools & different & different \\
\hline similar & cooperation & attraction \\
\hline different & supplementation & confrontation \\
\hline \multirow{2}{*}{} & STRATEGIC ALTERNATIVES
\end{tabular}

Fig. 1. Matrix of strategic alternatives based on convergence of objectives public and third sector approaches Adapted from: Najam. A. The Four C's of Government-Third Sector Relations. Non-Profit Management and Leadership. vol.10, №4, 2000. https://doi.org/10.1002/nml.10403.

The strategic alternatives in the presented matrix require specific approaches to relationship management and search for forms of cooperation and conflict resolution.

Within the framework of cooperation, the public and non-governmental sectors have similar goals and are largely ready for partnership, which implies reaching a consensus on the applicable methods, tools and initiatives to achieve the goals. This position is the most favorable, as it has no identified conflicts and oppositions, but a common view ahead and a willingness to cooperate.

In terms of complementarity, the goals pursued by public institutions and civil society structures are similar, but they have different views on the approaches to achieving them. In this case, the so-called alliance strategy is applicable, which in this case provides interaction based on different views, capabilities and capacities. Where a contradiction is possible, a common solution is reached by consensus.

In the location of attraction, we have different goals, but similar approaches to their achievement is permissible cooperation of efforts in order to achieve individual goals and synergistic effect of the interaction. In the presence of opposing and mutually exclusive goals, communication and consultative actions are initiated in order to achieve their maximum approximation and to choose a compromise option that does not harm any interested party.

In a confrontational location, both goals and approaches are diametrically different. In this case, it is very difficult to reach a consensus on a policy. Dialogue is a tool for reducing disparities, a wide range of information and clearly outlining policy factors and expected effects. The strategy sought is inclusive, but as this is an extremely long and complex process, in the first stage it is enough to reduce the confrontation by scoring points of reference for cooperation and change.

Applying an iterative model for applying the bottom-up approach to inclusion in integrated planning involves looking for key points of contact at each stage, defined by Elizabeth Rocha, who proposes the Ladder of Empowerment model (Rocha, 1997). This model presents a concept of individual and collective forms of empowerment, which is different from existing models that structure the dynamics and interaction between power and participation. It brings to the fore the building force, ie. the relationship between individual and collective participation and power, along with the factors that stimulate or hinder the building of power. The application of different instruments in the context of strategic alternatives based on convergence of objectives of public and third sector approaches must be based on a critical analysis of each of the five stages of the model, namely: 1. Atomistic individual empowerment; 2. Built-in individual authorization; 3. Intermediary authorization; 4. Socio-political empowerment; 5. Political empowerment. In this way, the effectiveness of the bottom-up approach in the process of integrated regional development planning can be achieved.

\section{DISCUSSION}

In practice, the public sector is the one that should drive the engine of civic participation, the initiator should be the one that creates conditions and has the resources to involve civil society structures in the processes of formulation, implementation and monitoring of public policies.

Civic participation needs an environment that allows for the integrity and effectiveness of organizations in dialogue with the authorities. The preconditions that are presented as necessary for real decentralization, based on the broad participation of society in regional policy (Kelly, 1999): 
- High level of work in the administration, based on the competence and expertise of employees. If this condition is not met, the involvement of civil society will hinder work rather than help.

- Between the interests of citizens that are operational in nature and those of the community that are of strategic importance and long-term impact there is a clear line.

- Necessary minimum competence and expertise of stakeholders in socio-political and administrative issues. The more stakeholders are competent, the more likely it is that an adequate solution will be reached that does not reflect a limited range of interests. Finally yet importantly, it should be borne in mind that the concentration of knowledge in a limited number of organizations creates the risk of manipulative actions and decisions in favor of certain interests.

- High level of trust between public and NGOs, achieved through cooperation, support, stimulated and encouraged participation. People, or most of them, must feel that their interests are protected by those in power, otherwise trust is illusory and the partnership too fragile.

Decentralization through civic participation has a role to play in democratizing society, achieving better public policies, social engagement and inclusion in social processes. This is indisputable.

The question is what participation, how, in what way, with what tools. Here, too, the leading role of the public sector emerges, of the power resources placed in the hands of elected officials and their political and administrative teams. The public sector has regulatory commitments arising from special laws (eg Public Finance, Regional Development Act, etc.) to ensure and promote participation in public policies. It should be noted, however, that the regulatory requirements ensure minimal inclusion - information and public discussion, which can be placed at the first levels of the ladder of civic participation. This means that participation is insufficiently effective and partly formal. In settlements where there are no traditions, support and incentives for participation, the non-governmental sector and civil society are passive and unconstructive. Partnership is an illusion and joint policy-making is impossible. Even if this statement sounds extreme, research on the subject shows that the opportunities for good cooperation between the public and the third sector have not yet been realized successfully. This stems from both objective factors and a lack of vision for ways to stimulate participation, limited expertise and a lack of good communication and effective constructive dialogue between representatives of individual organizations, both non-governmental and public.

\section{REFERENCE LIST}

Agrawal, A., \& Ribot, J. (1999). Accountability in Decentralization: A Framework with South Asian and West African Cases. Journal of Developing Areas 33, 473-502.

Ambrose , K. (2013). Decentralization and Citizens' Participation: Some Theoretical and Conceptual Perspectives. African Review Vol. 40, No. 2, 215-239.

Analyzes and models for improving citizen participation in the processes of formulation, implementation and monitoring of regional policy. (2019). Извлечено от https://www.ftr-bg.org/wpcontent/uploads/2019/09/14_\%D0\%90\%D0\%BD\%D0\%B0\%D0\%BB\%D0\%B8\%D0\%B7\%D0\%B8\%D0\%B8-\%D0\%BC\%D0\%BE\%D0\%B4\%D0\%B5\%D0\%BB\%D0\%B8-\%D0\%B7\%D0\%B0\%D0\%BF\%D0\%BE\%D0\%B4\%D0\%BE\%D0\%B1\%D1\%80\%D1\%8F\%D0\%B2\%D0\%B0\%D0\%BD\% D0\%B5-\%D0\%BD\%D0\%B0-\%D0\%B3\%D1\%80\%D0\%B0\%D0\%

Arnstein, S. (1969). A Ladder of Citizen Participation. Journal of the Royal Town Planning Institute 35, 4, 216-24.

Burns,, D., Hambleto, R., \& Hoggett, P. (1994). The Politics of Decentralization: Revitalising Local Democracy. Public and Politics, Houndmills:Macmillan.

Charter of Fundamental Rights of the EU. (2016). Извлечено от https://eur-lex.europa.eu/legalcontent/BG/TXT/PDF/?uri=CELEX:12016P/TXT\&from=EN

Cheema, G., \& Rondinelli, D. (2007). From Government Decentralization to Decentralized Governance. OT Decentralizing Governance: Emerging Concepts and Practices (стр. 170-188). Washington DC: Brookings Institution Press. 
Code of good practice for civic participation in the decision-making process. (October 2009 r.). Извлечено от https://rm.coe.int/CoERMPublicCommonSearchServices/DisplayDCTMContent?documentld=09000 016802eed5a

Collins, K., \& Ison, R. (2009). Jumping Off Arnstein's Ladder: Social Learning as a New Policy Paradigm for Climate Change Adaptation. Environmental Policy and Governance, 19, стр. 358-373.

Consolidated Version of the Treaty on EU. (2012). Извлечено от https://eurlex.europa.eu/resource.html?uri=cellar:2bf140bf-a3f8-4ab2-b506fd71826e6da6.0023.02/DOC_1\&format=PDF

Council of Ministers of the Republic of Bulgaria. (2010). Standards for public consultation. Извлечено от file://C:/Users/Owner/Downloads/standarti.pdf

Daynov, E. (2021). Civic participation. University Dictionary of the New Bulgarian University. Извлечено от https://nbu-rechnik.nbu.bg/bg/obsht-spisyk-na-ponqtiq/gra-zh-dansko-u-ch-astie

European Charter of Local Self - Government. (2017). Извлечено от https://rm.coe.int/the-congress-bookleteuropean-charter-of-local-self-government-bulgari/168098bb4f

European strategy for innovation and good governance at local level. (2007). Извлечено от https://www.mrrb.bg/bg/administrativno-teritorialno-ustrojstvo/dobro-demokratichnoupravlenie/evropejska-strategiya-za-inovacii-i-dobro-upravlenie-na-mestno-nivo/

Guide for evaluating participatory processes. Short Guides for citizen participation 3. (June 2013 r.). Извлечено от http://www.gencat.cat/governacio/pub/sum/qdem/guiesbreus_3_ang.pdf

Hristova, A., \& Andreeva, D. (2018). Civic activity with variable success. Bulgarian Center for Non-Profit Law, Sofiq.

INGO Conference. (1 October 2009 r.). Code of good practice for civic participation in the decision-making process. Извлечено от http://infopass.eu/cause/images/11_Kodex_dobri_praktiki.pdf

Kelly, M. (1999). Openness and Transparency in Governance: Challenges and Opportunities. NISPAcee.

Kraft, M., \& Furlong, S. (2020). Public Policy: Politics Analysis and Alternatives. 7th Edition, CQPress,.

Law on local self-government and local administration. (2021). Извлечено от https://www.lex.bg/bg/laws/ldoc/2132580865

Law on the Administrative and Territorial Organization of the Republic of Bulgaria. (2021). Извлечено от https://www.lex.bg/laws/ldoc/2133622784

Levinson, M. (2010). The Civic Empowerment Gap: Defining the Problem and Locating Solutions. От Handbook of Research on Civic Engagement (стр. 331-361). Hoboken, NJ: John Wiley \& Sons.

Litvack, J., \& Seddon, J. (1999). Decentralisation: Briefing Notes. Washington, DC: World Bank Institute.

Mechanisms and proposals for improving the environment for civic participation in the field of healthcare. (2019). Извлечено от https://bapemed.org/wp-content/uploads/2019/11/podobryavane-na-sredataza-grazhdansko-uchastie-v-zdraveopazvaneto.pdf

Mihaylov, A. (2012). Decentralization in Bulgaria or how to put things in the right places? Cities \& Regions Magazine, no. 6.

Najam, A. (2000). The Four C's of Government-Third Sector Relations. Non-Profit Management and Leadership. vol.10, №4.

Rebell, M. (2018). Chapter One. The Civic Participation Crisis- and the Civic Empowerment Gap. OT Flunking Democracy: Schools, Courts, and Civic Participation (стр. 13-33). Chicago: University of Chicago Press.

Recommendation CM/Rec(2007)14 of the Committee of Ministers to member states on the legal status of non-governmental organisations in Europe. (10 October 2007 r.). Извлечено от https://search.coe.int/cm/Pages/result_details.aspx?ObjectID=09000016805d534d

Rocha, E. (1997). Ladder of Empowerment. Journal of Planning Education and Research , 17, 31-44.

Rowe, G., \& Frewer, L. (2005). A Typology of Public Engagement Mechanisms Science. Technology, \& 
Proceedings of INTCESS 2022-9th International Conference on Education \& Education of Social Sciences 17-18 January 2022- Online Conference

Human Values 30, 251-90.

Therkildsen, O. (1988). Watering White Elephants? Lessons from Donor Funded Planning and Implementation of Rural Water Supplies in Tanzania. Centre for Development Research Publications 7, Uppsala: Scandinavia Institute of African Studies.

White, S. (1996). Depoliticising Development: The Uses and Abuses of Participation. Development in Practice, Vol. 6 No.1, стр. pp. 6-15. 